\title{
Zygmunt G. BARAŃSKi AND Lino Pertile (EDS.): DANTE in Context. CAmbridge: CAmbridge University Press, 2015. 571 PP. ISBN 9781107033146 (HBK)
}

\author{
MARÍa DOLORES CEREZO BARRAGÁN \\ UNIVERSITY OF CORDOBA
}

The volume edited by Zygmunt G. Barański and Lino Pertile represents a very detailed attempt to provide an interdisciplinary approach to the framework that surrounded Dante's life and works. A book which gathers the views of international scholars offering an overall perspective of the cultural, historical and intellectual life in Central and Northern Italy during the Late Middle Ages. Zygmunt G. Barański is Serena Professor of Italian Emeritus at the University of Cambridge and Notre Dame Chair of Dante and Italian Studies at the University of Notre Dame, and Lino Pertile is Carl A. Pescosolido Professor of Romance Languages and Literatures at Harvard University, and Director of the Harvard University Center for Italian Ranaissance Studies at Villa I Tatti, Florence.

Bracketed by an introduction, the work is structured in five sections consisting of a number of essays that provide the reader with an integrated and comprehensive overview of life in Italy around the year 1300. The edition is supplemented by a list of illustrations and maps, including a chronology, abbreviations and several notes on translations. In the opening pages, Zygmunt G. Barański and Lino Pertile give a general view of each thematic session and a detailed presentation of the twenty-five scholars and their contributions.

The first section of the volume, Politics and society (pp. 9-134) presents the economical, social and political realities of Italian context around the thirteenth century first decades. In the first chapter, 'Empire, Italy and Florence' (pp. 9-29), William Caferro provides an insightful analysis of the Italian politics during the late thirteenth and early fourteenth century. His analysis focuses on the relationship between the Empire and the Papacy as a key question along Dante's lifetime. As he notes, 'at its core lay the question of primacy of authority: 
whether the State or Church possessed plenitude of power, an issue that involved all of Christendom' (p. 10).

Casting light on the economic background of the period, William R. Day's chapter, 'Economy' (pp. 30-46), analyses the financial situation of Florence over a decade earlier than Dante's birth in 1265. The author emphasises the undisputed economic supremacy of Florence at that time, describing it as the largest city in Tuscany to play a leading commercial role in the region. Day's points out Florence as becoming one of the main commercial centres in Europe and the crib of the Italian Renaissance, as a result of demographic and economic growth. By way of a clarifying explanation focused on the relations between Florence and Pisa, the author emphasises that this economic upswing began more than a century before Dante's birth. The author connects the economic growth of Florence to the expanding of the city's walls to accommodate the increasing population. Furthermore, in this chapter, the private and ecclesial building growth taken place in Florence along the thirteenth century is stressed, yet it seems that these circumstances can be traced back to the second half of the twelfth century, when urban landscape was characterised by towers owned by Florence's most wealthy families.

The volume continues with a chapter devoted to the origins of cannon law and the transformation of cannon legality during the thirteenth century. Sara Menzinger's 'Law' (pp. 47-58) invites the reader to take a look at the politics and public law between the twelfth and fourteenth centuries pointing out the circulation of medieval political ideas. In that regard, the author highlights the translation of Aristotle's Politics from Greek into Latin by William of Moerbeke during the second half of the thirteenth century.

As a way of introducing different connotations in the use of the term 'justice' in Dante, Giuliano Milani's analysis (pp. 59-70) attempts to explain Dante's context use of 'justice' as a social experience and political conflict. The author clarifies that trials became a form of governing. In his explanation, he emphasises the notion of 'justice' as an instrument to legitimize private interests and political goals.

Holly Hurlburt starts a new section to the volume (pp. 71-82), where the focus moves to the gender relations during the Italian Late Middle Ages. As the author notes, 'men and women of the late medieval Italy were subject to a number of hierarchies and idealized notions. These structures stressed rich over poor, male over female, masculine over effeminate' (p. 82).

The chapter by George Dameron (pp. 83-105) takes us into a different setting, as he looks into the changes in the Florentine Church from the middle of the thirteenth to the beginning of the fourteenth century. The author notes how politics and religious ideas were 'inextricably intertwined in Dante's Florence' ( $p$. 85). 
Review: Zygmunt G. Barański and Lino Pertile (eds.), Dante in Context

In his 'Heresy and dissidence' (pp. 106-118), David Burr describes the thirteenth century as a 'period of spiritual and theological creativity' (p. 106). The author goes deep into the variety of heresies and heterodoxies during the Late Middle Ages as well as describes the thirteenth century as a period characterized by a 'genuine revolution in both the form and the content of university instruction' (p. 116). Burr emphasizes how one of the most important changes in content was 'precipitated' by the translation of Aristotle into Latin as some of the Aristotelian ideas 'contradicted' Christian principles.

The first section of this volume concludes with Edward D. English's approach to the 'great changes' in most aspects of daily life during Dante's years in Florence and Northern Italy.

The second section, Intellectual traditions (pp. 137-240), fleshes out the framework of thought at the time of Dante Alighieri, since the middle of the thirteenth to the fourteenth century. In seeking to elucidate the role of philosophy and theology in this context, Andrea A. Robliglio's 'Philosophy and theology' (pp. 137-158) considers the symbiosis between knowledge and religious faith as universal acceptance. The author explains in great detail this synthesis looking into the meanings of philosophy and theology throughout Dante's context. Regarding the first concept, Robiglio refers to philosophy as 'wisdom' (sapientia), which is considered not just as the highest and most fundamental outline of knowledge but also as an appropriate way of living based on Christ's teachings and Christian values. Robiglio highlights the variety of meanings that theology manifests in Antiquity and the High Middle Ages. Theology is not only used as the study of the Bible related to 'sacred doctrine' (sacra doctrina), it also relates to a 'particular science: the part of true philosophy that deals with God, with the incorporeal substances, and with the human soul, itself also incorporeal and immortal' (p. 138).

In order to explain the status of philosophy and theology in the late Middle Ages, Robiglio considers the following historical factors as being essential: the establishment of the mendicant orders, the birth of the universities and the church reform. In keeping with the first factor, Robiglio underlines the foundation of new religious orders over the first decade of the thirteenth century - the Franciscans and the Dominicans in particular. By the end of the century, religious education in Florence and Northern Italian cities was under the control of the previously mentioned orders; and regarding the second factor (the development of higher education and the birth of the universities), the author points out the 'veritable pedagogical renaissance' of the episcopal schools during the twelve century due to the wide circulation of newly translated Arabic and Greek philosophical texts. The author connects the third issue, the Catholic Church's Reformation, to: 'the imperative to exercise greater control over the 
behaviour of the clergy and the desire to bring about a religious cultural renewal' (p. 142).

With the aim of defining Dante's intellectual context, Robiglio conceives his philosophical and theological background as a central element in understanding Dante's poetry. Even though the author refers to Dante's brief and irregular contacts with the Florentine schools of the mendicant friars, he clarifies it in relation to theological issues, Dante was mainly self-taught. On this basis and in order to understand Dante's intellectual framework, the author considers it is essential to recognize the impact of mediating factors and extra-academic intellectual traditions. Robiglio's attempt to provide an overview of this context, preaching is considered as a key means of mass communication in Late Medieval urban environment. In this chapter, it is indicated the quick spread of the studia of the religious orders throughout Italian cities in the second half of the thirteenth century. Particularly, Robiglio concentrates on the teaching offered by those orders - theology and a two-years introductory philosophical learning heavily rooted in Aristotle's writings.

Luca Bianchi's 'Moral philosophy' (pp. 159-172) provides an explanation to Dante's conception of 'moral philosophy' and 'moral science' as 'the part of wisdom that establishes what is good, how human beings should act, and which kind of life is best for them' (p. 159). For the purpose of elucidating Dante's own view on ethical issues, the author considers it essential to describe the paradigms of moral philosophy and theology by which Dante was influenced. Bianchi recognizes that Latin moral thought, specially Cicero and Seneca, and the Roman juridical tradition impacted on Dante's approach to ethical matters; the Bible, the Church Fathers and Christian moral compilations are also perceived as sources for discussing moral problems that influenced Dante's thought.

Bianchi references the Nicomachean Ethics as the Aristotelian work to which Dante refers to when he speaks of ethics, as well as the 'handbook' to teach moral philosophy from the thirteenth century onward. Moreover, the role of ethics as a discipline to be studied based on philosophical sources is described by the author as a turning point in the history of medieval thought. Bianchi's approach enlightens us on taking into consideration philosophical ethics as 'an autonomous field of research that could be explored rationally without recourse to theological principles' (p. 161). Unlike in logic, physics, and cosmology, the author establishes that Aristotle's supremacy in ethics was questioned by classical and Christian authors such as Cicero, Seneca, Augustine, and Boethius.

It is worth bearing in mind the elucidations on the evolution of physics during the period from 1250 to 1350 given by Edward Grant in chapter eleven, 'Natural Philosophy' (pp. 173-188). The author begins by attaching great importance to this period of time referring to the radical changes that transformed the intellectual life of western Europe in 1250. Grant mentions the translation of 
Review: Zygmunt G. Barański and Lino Pertile (eds.), Dante in Context

Aristotle's natural philosophy into Latin from Arabic and Greek, noting the importance of the translations of Aristotle's natural philosophy from Greek by William of Moerbeke in the 1260s. As the author explains, Aristotle's treatises on natural philosophy formed the basis of the curriculum in the Faculties of Arts in the two new universities of Paris and Oxford. This chapter offers insight into the relationship between natural philosophy and theology, emphasizing that during the late Middle Ages, theologians could use natural philosophy to explain theology. On the contrary, the author clarifies that theology was not used by natural philosophers who were not theologians in the explanation of natural philosophy.

Except for the ideas contrary to the tenets of faith, Grant elucidates that almost all of Aristotle's basic ideas about the cosmos were adopted by medieval natural philosophers. In this chapter is stressed Aristotle's belief in an eternal, uncreated world that would never end as one of the Aristotle's unacceptable ideas. Above and beyond the explanation of the Aristotelian theory about the cosmos, some of the major topics considered by scholastic natural philosophers in their treatises on Aristotle's natural philosophy are provided in a clear and accurate manner. The last section of this chapter deals with the inheritance of medieval natural philosophy, describing the late Middle Ages, mainly the period 1250-1350, as a time that left a profound legacy to western Europe.

In 'Medicine' (pp. 189-199), Michael R. McVaugh examines the 'number of themes' that characterize medicine in the western Mediterranean world during the Late Middle Ages. In an attempt to demonstrate the 'growing appreciation' of academic learning, the author describes it as a 'process that led not only to increasing numbers of medical practitioners with some claim to academic learning in subject, but to a social willingness to concede that the expertise of such physicians entitled them to exert authority over matters that had previously been left to individual decision or municipal degree' (p. 190). McVaugh clarifies that this movement was characterised by the recovery of the writings of Galen, pointing out that many of these were translated from Arabic or Greek in the twelfth century.

Luis M. Girón's 'Islamic and Jewish influences' (pp. 200-220) represents an attempt to establish 'direct cross-cultural exchanges' between Muslims, Christians, and Jews during the later Middle Ages in Italy.

In 'Cosmology, geography and cartography' (pp. 221-240), Theodore J. Cachey, Jr. takes us into a different setting as he examines the cosmological knowledge during the Late Medieval period. The author clarifies that the image of the universe is 'exquisitely represented in The Creation of the World (c. 1445), a tempera on panel painting by the Siense Giovanni di Paolo (1398-1482), long believed to have been inspired by the cosmology of Dante's Commedia' (p. 221). 
Particular account shall be taken of Theodore Cachey's analysis, together with Mc Vaugh's outlook on the Medicine in the western Mediterranean world and Grant's explanation on the evolution of physics. These chapters represent a great attempt to offer the reader insights into different late medieval scientific issues.

The third section of this book, Linguistic and literary cultures (pp. 243-398), not only examines the linguistic and literary cultures, but also deeps into the levels of education, popular culture and journeys to the other world. Starting with a question, Mirko Tavoni starts his essay presenting the main goal of his approach: 'What language or languages were spoken and written in different social situations in Italy during Dante's time?' (p. 243). Tavoni's 'Linguistic Italy' (pp. 243-259), highlights the 'environment of vernacularizing from Latin, beginning in the last decade of the Duecento' (p. 253).

A description of the education system and syllabus in the city of Florence during the later Middle Ages takes place in Robert Black's 'Education' (pp. 260276). The author begins by describing the later medieval Florentine society using the words 'highly literate' as a result of a fairly developed education system and syllabus. Robert Black provides a complete picture about the three types of schools during the late Middle Age, starting with elementary schools in which basic reading was taught using Latin as a language of instruction. The next stage was devoted to learn how to write in Latin in grammar schools. The author emphasises how the grammar curriculum in later medieval Italy was not only composed by elementary reading, Latin grammar and Latin literature, but also stylistics and rhetoric were included in it. The author mentions the importance of Latinity in Dante, for whom Latin was 'the first art'. Offering an explanation of Dante's academic discipline, Robert Black points out that he was 'self-taught', noting that after 1290, Philosophy became Dante's obsession. Blank's analysis is follow by a chapter on rhetoric, literary theory, and practical criticism (pp. 277296), in which Ronald L. Martinez focuses on the Rhetoric in the Duecento citystate.

Robert Black's 'Classical antiquity' (pp. 297-318) delves into the study of the heritage of classical antiquity noting that the apogee of classical studies in medieval Italy was reached in the twelfth century' (p. 297). The author provides the reader with a more in-depth understanding of ancient Latin authors focusing on their influences on Dante's writings. Meanwhile, Peter S. Hawkins's 'Religious culture' (pp. 319-340) offers insight into the characteristic features of the religious character of Dante's culture. His approach to this issue begins with an overview of the Christian life in Dante's time. Hawkins emphasizes the 'spiritual matrix' within the Medieval city's life. 
Review: Zygmunt G. Barański and Lino Pertile (eds.), Dante in Context

In 'Visions and journeys' (pp. 341-353), Eileen Gardiner analyses the genre of voyage and vision separately so that the reader could 'appreciate fully their vitality and complexity at the beginning of the fourteenth century' (p. 341).

Ending the section on Linguistic and literary culture John C. Barnes examines historical and political literature as 'overlapping categories' in 'Historical and political writing' (pp. 354-370). The last two chapters of the third section by Paolo Cherchi (pp. 371-388) and Jan M. Ziolkowski (pp. 389-398) examine the vernacular literatures and popular culture during Dante's context respectively.

Visual and performative culture (pp. 401-457) is the fourth part of the book which provides a detailed synopsis of the significant changes occurred in the field of the art, architecture and music. In the chapter twenty-four, 'Illumination, painting and sculpture' (pp. 401-426), Louise Bourdua focuses on the visual culture of Dante's context. At the beginning of this section, the author exposes that Dante is often described as 'a very visually observed', which is partly explained due to his contact to the 'rich visual culture' that surrounded him in Florence and Tuscany, where he spent the early years of his life, and in Northern Italy (Verona) and Ravenna, in which he ended his life. Bourdua highlights that Dante was largely relied on by visual stories, by referring to Dante's knowledge about pitture infamnati. In this chapter, it is also underlined that the artist's stay in Florence to the beginning of what the author describes as the artistic revolution in monumental painting and sculpture.

Areli Marina's 'Architecture and urban space' (pp. 427-447) examines the factors that conditioned Italian architectural and urbanistic 'reanissance' during Dante's context. The author emphasises the heritage of ancient Rome and political fragmentation as key elements that should be considered in the changes that occurred in the field of architecture.

Throughout his 'Music' (pp. 448-457), Michael Scott Cuthbert delves into the study of the framework that characterises the musical context during the end of the thirteen century and the mid-fourteenth century. The author considers the Plainsong as the most important and persuasive musical tradition, which is defined as follows: 'a set of codified relationship between music and words sung at the daily Mass and, especially in monasteries and the large churches' (p. 448). Cuthbert points out that interval theory was gradually more separated from compositional practices. In this approach, the madrigal, caccia and ballata are considered to be the main Italic poetic forms that were set musically during the Trecento. Whereas the first two pieces began their existence as polyphonic genres, the author considers the ballata as monophonic pieces.

The last section of the book, Dante: life, works, and reception (pp. 461-537) proposes an update description of Dante's biography and the textual transmission. Lino Pertile's 'Life' (pp. 461-474) provides a description of those events which shaped 
Dante's life-story, focusing on his early life, Florentine politics, exile, Henry VII's Italian campaign, the amnesty and the last years. As mentioned above, Dante discovered Philosophy in 1290, when Beatrice, the love of his life, died. The author considers Beatrice's death as a crucial event in Dante's life that led him closer to his favourite studies. Pertile describes that after the death of Beatrice, he began reading Boethius and Cicero, a life-changing experience whereupon he discovered Philosophy. In respect of Florentine politics, the author refers to the cause of Dante's exile, after he was charged with corruption and financial extortion, opposition to the Pope, and complicity in the banishment of the Blacks from Pistoia.

The chapter twenty-eight, 'Works' (pp. 475-508), represents an endeavour to describe Dante's work, in which Lino Pertile presents his writings interwoven with historical events, poetic autobiography and refection on poetry. The author deeps on the analysis of the Commedia, describing it as 'a summa of medieval cultural, a synthesis of all facets of reality as an integral whole - earthly and heavenly, physical and spiritual, natural and historical, cultural and ethical' (p. 490). According to the title, the context use of the word 'Commedia' Pertile sees its meaning and motivation as a controversial issue. The author not only refers to the rhetorical nature of the poem, but also he explains its meaning stating that 'the poem is called a 'comedy' because it narrates Dante's salvation - an experience that is 'comic' in the medieval sense that it leads to a happy conclusion' (p. 492).

In the final two chapters of Dante in Context, 'Textual transmission' (pp. 509517) and 'Early reception' (pp. 518-537), Zygmunt G. Barański provides the reader with a great overview on the 'modalities' by means of which Dante's works were transmitted, received and read, in particular during the two centuries after his death, 'which highlights how Dante's engagement with the world continues, indeed grows, beyond his own life' (p. 3). This is particularly relevant from the perspective of the cultural transfer in the Middle Ages as the transmission and reception of the text represents an essential element in the transferences of knowledge in the Medieval World.

Finally, it is worth noting that the intellectual context in which Dante lived and worked reflects the characteristic features of the cultural transfer in the late Middle Ages. With a view to illustrating the intellectual life of the twelfth and thirteenth centuries, the second part of this volume brings to light the transmission of knopwledge through the translation of philosophical texts. Chapter nine highlights the wide circulation of newly translated philosophical texts from Arabic and Greek, whereas chapter eleven refers to the translation of Aristotle's natural philosophy into Latin from Arabic and Greek. This analysis emphasises the translations of Aristotle's natural philosophy from Greek by 
Review: Zygmunt G. Barański and Lino Pertile (eds.), Dante in Context

William of Moerbeke in the 1260s. The translation of philosophical texts involves the transmission of knowledge in which forms of interpretation are included. Texts have been subjected to transformations reflecting the dynamic nature of the cultural transmission during the Middle Ages.

The volume is certainly an outstanding work that sheds a new light on Dante's biography and writings by describing the context that surrounds him, with the exception of the first two chapters of the last section focused specifically on Dante's life and works. Dante in Context represents the final outcome of the commendable efforts to provide the reader with a complete and detailed picture of the cultural, historical and intellectual conditions determining Dante's life and works. 